Article

\title{
A New Viewpoint to the Agatha Problem: Who Was the Mother of Margaret, Queen of Scots?
}

Gyula Pályi

Citation: Pályi, Gyula. 2022. A New Viewpoint to the Agatha Problem: Who Was the Mother of Margaret, Queen of Scots? Genealogy 6: 22. https://doi.org/10.3390/ genealogy6010022

Received: 29 November 2021

Accepted: 1 March 2022

Published: 7 March 2022

Publisher's Note: MDPI stays neutral with regard to jurisdictional claims in published maps and institutional affiliations.

Copyright: (C) 2022 by the author. Licensee MDPI, Basel, Switzerland. This article is an open access article distributed under the terms and conditions of the Creative Commons Attribution (CC BY) license (https:/ / creativecommons.org/licenses/by/ $4.0 /)$.
Department of Life Sciences, University of Modena and Reggio Emilia, I-41100 Modena, Italy; gyula.palyi@unimore.it

\begin{abstract}
The family background of Agatha, the mother of Margaret of Scotland, is still one of the not yet fully clarified questions of Medieval European history. Here, the possibility that she could have been the daughter of Prince Imre, heir of the Hungarian throne, from the Árpád family and his wife, daughter of Romanos III Argyros, Emperor of the East Roman Empire, is discussed.
\end{abstract}

Keywords: Wessex Margaret of Scotland; Scots, Queen Margaret of; Queen Margaret, Mother of; Agatha, Mother of Queen Margaret; Agatha, father of, Imre; Crown Prince of Hungary, father of Agatha

\section{Introduction}

Margaret, royal princess from the family of the Kings of Wessex and, later, of England $\left({ }^{*} 1045 / 47,+16\right.$ November, 1093) (data and references regarding persons appearing in the present study are presented in Appendix A), married Malcolm III King of Scots approximately in 1069 and, as Queen of Scots, became a key figure in Scottish cultural and religious history. Even if Margaret's father descended from one of the best-documented families of medieval Europe, the identity of her mother, Agatha, is still one of the interesting unresolved challenges of genealogical research, even today, almost a millennium later. In the present paper, a theory is described, according to which Agatha might have been the daughter of Crown Prince Imre of Hungary (Árpáds) and his wife, the daughter of Romanos III Argyros, Emperor of the East Roman Empire.

The father of Margaret, Prince Edward the Exile ( ${ }^{*}$ ca.1016, +4 April, 1057), son of King Edward II, Ironside, had to leave England together with his brother Edmund because of political turbulences at a very young age, and after a few transfers, he found a relatively quiet exile in the Hungarian Kingdom, at the latest, in 1040 (there is a Hungarian estate around Réka Castle named Terra Britanorum de Nádasd, by tradition granted by King Stephen I (István I) of Hungary to the English Edward (Koller 1782; Horvát 1828; Xantus 1878; Rézbányay 1896; Malcomes 1937, 1938; Papp 1967; Szakonyi 2020), which if this tradition is true, would put him in Hungary before Stephen's death in 1038). According to another view, Margaret's family came to Hungary from Kiev together with another exile, Prince Andrew / András who became King of Hungary in 1047 (Jetté 1996; Keene 2011, 2013). In Hungary, Edward appears as husband of this (mysterious) Agatha, who is the focus of several earlier research efforts and of the present study. It is well documented that Edward turned back to England from Hungary in 1057, already married and as the father of a son and two daughters (one of these was Margaret, later Queen of Scots). Prince Edward died a few days after having returned to his homeland (e.g., Ronay 1989). Soon thereafter, the family of Prince Edward the Exile had to flee again, this time to Scotland. There, one of his daughters, Margaret, married Malcolm III (from the family of the Kings of Scotland). The identity (family background) of Margaret's mother, Prince Edwards's wife Agatha, awoke the curiosity of historians after a few centuries (e.g., Reusner 1592; Pray 1763; Cornides 1778; Katona 1779; Xantus 1878) without any final solution so far 
(Baldwin 2010, Conclusion: "given the current stage of knowledge, it is not possible to assign a specific parentage to Agatha, which carries conviction"). As often happens to difficult scientific problems, there are numerous hypotheses about her origin. These include German (Katona 1779; Pray 1763; Karácsonyi 1928; Herzog 1939; de Vajay 1962, 1971; Kraentzler 1978; Faris and Richardson 1998; Klaniczay 2002; Parsons 2002; Wolf 2011), Hungarian (see below), Polish (Ravilious 2009; Guido and Ravilious 2012), Bulgarian (Mladjov 2003), Russian (Wunder 1975; Ronay 1989; Jetté 1996; Ingham 1998; O’Brien 1999; Pavsic 2001; Humphreys 2003, 2004; Hlawitschka 2006; Keene 2011, 2013; Raffensperger 2012, 2016, 2018), Danish (Reusner 1592; Felch 1894), and Byzantine (Felch 1894; Humphreys 2004) origins (generally her descendance was supposed/deduced from the highest ranking families of these countries and/or even cross-variants of these families). Agatha studies are based on a few more-or-less contemporary informations from chronicles (Anglo-Saxon Chronicle, 1057, Cubbin 1996; Pretz 2012; John/Florence of Worcester 1881, ca. 1118; Thomson and Winterbottom 2003; Chibnall 1980; O’Brien 1999, ca. 1130; Hardy and Martin 1888; Dunphy and Bratu 2016) describing circumstances that are often contradictory. The studies concerned with the ancestry of Agatha have been reviewed several times; therefore, here we cite only a few relatively recent sophisticated publications that excellently cover and evaluate the relevant results and speculations (Lauder-Frost 2002; Humphreys 2003; Baldwin 2010; Wolf 2011; Keene 2011, 2013; Raffensperger 2012, 2016, 2018; Fest [1940] 2020; James 2021; Wikipedia Foundation 2021).

Our hypothesis, described later in this paper, is more-or-less in line with those variants, according to which Agatha was of Hungarian origin (chronicles: Thomson and Winterbottom 2003; Chibnall 1980; Hardy and Martin 1888; Dunphy and Bratu 2016—studies: Cornides 1778; Bresslau [1879] 1884; Fest 1935, 1938, Fest [1940] 2020; Moriarty 1952; Barrow 1993; Czigány and Korompay 2000; Sauser 2000; Lauder-Frost 2002; Mladjov 2003, 2015). These theories include the possibilities that she was the daughter of Granduke Géza ( ${ }^{* 940 / 45,+1 ~ F e b r u a r y, 997), ~ t h a t ~ i s, ~ s h e ~ c o u l d ~ h a v e ~ b e e n ~ a ~ s i s t e r ~ o f ~ K i n g ~(S a i n t) ~ I s t v a ́ n ~}$ [Stephen] I (*969/75, +15 August, 1038); the daughter of István I and his wife Gisela of Bavaria (Liudolfinger/Ottonen-Bayern, *ca.985, +7 May, 1065); or the daughter of one of István's successors, Salamon $\left({ }^{*} 1052,+1087\right)$ and his wife Judith Maria $\left({ }^{*} 1054,+1092 / 96\right)$, who was the daughter of Emperor Heinrich III (Salier, *28 October, 1017, +5 October, 1056, Schwennicke 1998, Table 12). Against each of these possible variants, however, powerful counter arguments can be found (e.g., Baldwin 2010). On the other hand, it is accepted by some scientists (first, in Hungary, e.g., Fest 1935, 1938, Fest [1940] 2020; Malcomes 1937, 1938) that Margaret was born in the Hungarian Kingdom, which makes the Hungary-based options attractive.

The theories deducing Agatha's German origin have their strong supporting argument based on the primary sources cited earlier in this paper (which identify Agatha as a "niece/daughter of Emperor Heinrich"), and this is coincident with the fact that István's wife Gisela came from a German (Liudolfinger-Bayern, Schwennicke 1998, Table 10) family, involving also the Hungarian royal dynasty in the chain of family relations.

The option that Agatha might have been the daughter of István and Gisela (Cornides 1778; Fest 1935, 1938, Fest [1940] 2020; Moriarty 1952) has the advantage that it joins the supporting arguments both for Agatha's Hungarian and German origin. The hypothesis described below has the same advantage.

\section{The Imre Hypothesis}

The most convincing counterarguments against the earlier Hungary-based theories are of biological character. Agatha is supposed to have been born some time between 1023 and 1030 (see, e.g., Wolf 2011, p. 508). Géza died decades before these dates (997); thus, the "sister-of-István" theory can be excluded with a high level of certainty. At the time mentioned, István and Gisela were fairly old, with István in his 50s and Gisela around or over 40. However, István, who introduced far reaching reforms in Hungary, had a strong ambition (well-documented, Szentpétery and Balogh 1938; Bollók and Kristó 2020) for his 
heir to continue his work, and when he lost his only grown-up son, Imre, in 1031, he and his wife might have made a desperate attempt to obtain an heir after Imre's death (which, if true, could have been a girl, Agatha), but this variant seems to be fairly improbable. One of István's successors, Salamon, on the other hand, was much too young even if his family relation had the same Hungarian/German characteristic that István had; he was born in the years when Margaret was born (and not Agatha!) — thus, this variant (Chibnall 1980) can also be excluded.

There was, however, a member of the Árpád family who fits very well within these requirements of age. István and Gisela's son, Imre (Gombos 1938; Kurcz 1983; Török 1986, 1994; Nemeskürty 1993; Magyar 2000; Barna 2006; Bradács 2008) was born in 1007, married in 1022 (to the daughter of Byzantine Emperor Romanos III Argyros), and passed away on September (November?) 2, 1031 (Schwennicke 1984, Table 153). Thus, he had 9 years of marriage exactly in the period when Agatha was supposed to have been born. Moreover, Imre had the same Hungarian/German descendance that could fulfil a compromise between the Hungary-based and Germany-based ("niece of Emperor Henry") theories of the origin of Agatha. Religious tradition describes (Érszegi 2001) Imre as a person, restraining (chastity, Lat.: continentia) himself from conjugal life, but this might be regarded as a somewhat exaggerated fruit of religious spirit and became popular during later dates (from the 12th century) (Concilium 2002; Kniewald 1939; Schmale 2002; Zapp 2002; Bartók and Horváth 2019). Other documented facts about Imre have shown that he was educated (Nemeskürty 1993; Török 1994; Magyar 2000; Érszegi 2008) to the fairly sportive life of rulers of the Middle Ages; he was sent to be a leader of military missions by his father and resolved these successfully. The circumstances of his death (boar-hunting) show again a manlike life-style too. Thus, it can reasonably be concluded that in the 9 years of his married life, he might have conducted a usual conjugal life-which, on the other hand, would be by no means in contradiction with his strong religious commitment.

The involvement of Imre and his wife in the ascendence of Agatha, similar to a (supposed) daughter of István and Gisela, has the same intermediary characteristic of providing both Hungarian and German ascendence (from Imre's side) as it would be for a sister of Imre. There is, however, no trace in the relevant documentation that a daughter of István I and Gisela arrived at adult age or that Imre and his wife had a child. These considerations point at the necessity of future research.

There is an additional interesting (onomastic) point in the possibility that Imre could have been the father of Margaret's mother. Agatha in Western and Central Europe is a fairly rarely given name. Agatha is of Greek origin (Kohlheim and Kohlheim 2007), and it was more frequently used in the Byzantine Empire. Actually, one of the grand-grandmothers of Imre's wife was named Agatha (Runciman 1929; Ostrogorsky 1968; Cheynet and Vannier 2003; Ravegnani 2006, 2008). Moreover, this (grand-grandmother) Agatha was the daughter of Emperor Romanos I Lekapenos (ca.870-15 June 948), who was married to an earlier Romanos Argyros, grandfather of Emperor Romanos III, and this marriage was a key event in the (social and political) ascent of the Argyros family, culminating later in the imperial throne. The habit of giving names of famous progenitors to new-born family members was present also in the Byzantine Empire.

Imre's given name also can be commented upon. According to some sources originally, he was called Heinrich (Schwartz 1930; Kristó 2000; Szabó and Sudár 2021), most probably referring to Gisela's influential German relatives (this is in consonance with the information that Imre's older brother, who passed away young, was named Otto). It cannot be determined with certainty when and why this name change took place, but it may have caused some confusion for later historians. For example, as husband of the daughter of Romanos III Argyros, some sources write Heinrich (e.g., Italian Wikipedia), which may also be due to this uncertainty in Imre's given name. In the present study, however, we accepted the data provided by Detlev Schwennicke in his fundamental work Europäische Stammtafeln (Schwennicke 1984, Table 153). 
If Agatha was in fact the daughter of Imre and she was born in the period between 1022 (Imre's matrimony) and 1031 (Imre's death), she might have been fairly young (7 to 16 years old) when king István I passed away in 1038. Being young and being a woman, she was "out of the game" at the turbulent events accompanying the succession to the throne. In fact, in the following years, six persons changed alternately on the Hungarian throne (one of these twice), which was occupied by István I for 41 relatively quiet years (Péter (first time), Sámuel, Péter (second time), András I, Béla I, Salamon, and Géza I), until longer, stable periods came after 1077 with (St.) László I (18 years) and Kálmán (21 years). It can reasonably be assumed that Agatha looked for matrimony as soon as she could, and in fact, we find her to be a mother of three children when leaving from Hungary to England in 1057.

It might be additionally considered that if Agatha had been exclusively of German origin, she (and later her family) could have found a more quiet, safe, and respected place in the German (Holy Roman) Empire than in Hungary, which experienced a climate of political instability for a few decades after the death of István I in 1038.

It is an interesting aspect of the genealogy of Agatha (and Margaret) that, if Agatha were a descendent of King István I, she could have been one of the pretenders of the Hungarian throne. As we mentioned above, it appears that she (and her husband) did not have such ambitions, at least as it is seen from the vast majority of the literature dealing with 11th century Hungary. However, there is one exception in this literature. Gaimar, in his poetic, literary chronicle (Hardy and Martin 1888), describes a visit of Edward the Confessor (before he became King) to Hungary with the goal giving some kind of "support" to the political ambitions of his cousins in Hungary. The extent of historical truth behind this description can be debated, but it still gives an indisputable proof of the fact that the possibility of the English princes in Hungarian exile being (at least) considered as participants in the rivalry for the Hungarian crown after the death of István I was a part of public discourse. This gives an argument for the view that Agatha, the wife of one of these princes (Edward), was a close relative of the prestigious monarch István I, who passed away in 1038. The exact nature of this relation is not documented, but there are not too many choices. The possibility that Agatha could have been the sister of Queen Gisela can be ruled out on the basis of age (Gisela's father died in August 995), and the possibility that Agatha could have been the daughter of one of the sisters of István I (e.g., Mladjov 2015) can be ruled out on the basis of the widely accepted German family relation; then, there remains nothing else than to consider Agatha either the daughter of István I and Gisela or as the granddaughter of the same couple. On the basis of the biological arguments mentioned above, this last possibility seems to be more realistic. If so, then, Agatha can be considered no other than the daughter of Crown Prince Imre and his wife, as described earlier in this paper.

The (possible) chain of descendance István I/Gisela $=>$ Imre/Argyra $=>$ Agatha $/$ Edward => Margaret/Malcolm III => David I has yet another unusual feature: the persons in these five generations, who are indicated here in boldface letters, lived their religious commitments at such a high level that they became canonized (declared to be blessed or saint) by the Roman Catholic Church. One could add that Queen Gisela's brother, Emperor Henry II (+1024), became canonized (1046); that Queen Margaret's daughter Mathilde/Editha of Scotland $\left({ }^{*} 1079,+1118\right.$, Schwennicke 1984 , Table 89$)$ was also known as an outstandingly pious person even if she did not become canonized (Huneycutt 2003; Green 2006; Keene 2011, 2013); and that the brother of the grandfather of Edward the Exile, King Edward II, the Martyr (+18 March 979, Schwennicke 1984, Table 78; Yorke 1999), became canonized in 1001. Obviously, there is no natural law in genetic biology that could prove that "sanctity" is hereditary, but strong character features, together with the physical appearance of living organisms, are frequently hereditary (e.g., Bouchard and Loehin 2001; Mufanò and Flint 2011; Zwir et al. 2020). One could say that ruling families had "good contact" with the Church and thus their merits became more recognized than those of "ordinary" citizens, but several counter arguments can be found against such a perspective, starting from the saints from the poorest parts of society or of the most ascetic life-style (e.g., Francis of Assisi, 
1181/2 - 2 October, 1226, canonized in 1228) or considering Emperor/King Carl (Károly) I (IV) Habsburg-Lothringen ( ${ }^{*} 17$ August 1887, +1 April 1922, beatified in 2004), who was the first beatified member of his family (having ruled in various countries of Europe for nearly a millenium, also giving a number of emperors), as a counterpoint. Thus, we can dare say that the above chain of canonized persons is not a result of political influence but rather can be considered as a noticeable indication of a close family relation between the persons mentioned above.

\section{Conclusions}

We put forth a hypothesis that the father of the mother of Margaret of Scotland, Agatha, could have been Prince Imre (son of King István I of Hungary, from the Árpád family and heir of the throne in the Hungarian Kingdom, who died before his father died and that royal succession in Hungary thus took different routes). Imre was married for 9 years before his early death in 1031 at the age of 24 years. The dates known about this prince fit very well in a possible time-frame around Agatha's life.

It should be pointed out that this theory is put forth as a possibility of a new direction in this area of research, which merits and needs deeper future investigations.

Funding: This research received no external funding.

Institutional Review Board Statement: Not applicable.

Informed Consent Statement: Not applicable.

Data Availability Statement: Not applicable.

Acknowledgments: The author thankfully acknowledges advice obtained from the late Géza Érszegi (+2022), László Szilágyi (+1978), János Wettstein (+2006) as well as from the two anonymous reviewers from Genealogy.

Conflicts of Interest: The author declares no conflict of interest.

\section{Appendix A}

Table A1. Persons, (family), status, dates, and references.

\begin{tabular}{|c|c|c|c|c|c|c|c|}
\hline Name & (Family) & Status & Born & Deceased & Married & Remarks & Notes \\
\hline \multirow[t]{2}{*}{ Margaret } & $\begin{array}{l}\text { (Wessex- } \\
\text { England) }\end{array}$ & $\begin{array}{l}\text { Queen of } \\
\text { Scots }\end{array}$ & $(?)$ & $\begin{array}{c}16 \text { November } \\
1093\end{array}$ & ca. 1069 & $\begin{array}{l}\text { Rom. Cath. } \\
\text { Saint }\end{array}$ & ES.II.T.78. \\
\hline & & & (1045) & $\begin{array}{c}16 \text { November } \\
1093\end{array}$ & $1069 / 70$ & $\begin{array}{l}\text { Rom. Cath. } \\
\text { Saint }\end{array}$ & ES II.T.89. \\
\hline \multirow[t]{2}{*}{ Edward } & (Wessex- & Prince & (?) & 1057 & (?) & "the Exile" & ES.II.T.78. \\
\hline & & & (?) & 19 April 1057 & (?) & "the Exile" & ESXXIX.T.36. \\
\hline \multirow[t]{2}{*}{ Agatha } & $\begin{array}{c}\text { (Brunonen- } \\
\text { Braunschweig?) }\end{array}$ & Princess & (?) & (?) & $\begin{array}{l}\text { Edward the } \\
\text { Exile }\end{array}$ & - & ES.II.T.78. \\
\hline & & & (?) & $1067 / 68$ & $\begin{array}{l}\text { Edward the } \\
\text { Exile }\end{array}$ & - & $\begin{array}{c}\text { ES:XXIX.T.36. } \\
\left({ }^{*}\right)\end{array}$ \\
\hline \multirow[t]{2}{*}{$\begin{array}{l}\text { Malcolm } \\
\text { III }\end{array}$} & (Scotland) & $\begin{array}{l}\text { King of } \\
\text { Scots }\end{array}$ & (?) & $\begin{array}{c}13 \text { November } \\
1093\end{array}$ & $\begin{array}{c}\text { 1069: } \\
\text { Margaret }\end{array}$ & - & ES.II.T.78. \\
\hline & & & 1031 & $\begin{array}{c}\text { (war) } 13 \\
\text { November } \\
1093\end{array}$ & $\begin{array}{c}\text { (2nd) 1069/70: } \\
\text { Margaret }\end{array}$ & - & ES.II.T.89. \\
\hline David I & (Scotland) & $\begin{array}{l}\text { King of } \\
\text { Scots }\end{array}$ & (1080) & 24 May 1153 & $1113 / 4$ & $\begin{array}{c}\text { son of } \\
\text { Margaret }\end{array}$ & ES.II.T.89. \\
\hline
\end{tabular}


Table A1. Cont.

\begin{tabular}{|c|c|c|c|c|c|c|c|}
\hline Name & (Family) & Status & Born & Deceased & Married & Remarks & Notes \\
\hline Edward II & $\begin{array}{l}\text { (Wessex- } \\
\text { England) }\end{array}$ & $\begin{array}{l}\text { King of } \\
\text { England }\end{array}$ & $(?)$ & $\begin{array}{c}\text { (murder) } 30 \\
\text { November } \\
1016\end{array}$ & $\begin{array}{l}1016 \text { N. } \\
\text { Eldgyth }\end{array}$ & “Ironside" & ES.II.T.78. \\
\hline Edward III & $\begin{array}{l}\text { (Wessex- } \\
\text { England) }\end{array}$ & $\begin{array}{l}\text { King of } \\
\text { England }\end{array}$ & (1004) & 5 January 1066 & $\begin{array}{l}\text { 1.23.1045, } \\
\text { Wessex E. }\end{array}$ & "Confessor" & ES.II.T.78. \\
\hline Harold II & $\begin{array}{l}\text { (Wessex- } \\
\text { England) }\end{array}$ & $\begin{array}{l}\text { King of } \\
\text { England }\end{array}$ & (1020) & $\begin{array}{c}\text { (war) } 14 \\
\text { October } 1066\end{array}$ & $\begin{array}{l}\text { 1065, Mercia } \\
\text { Ealdgyth }\end{array}$ & - & ES.II.T.78. \\
\hline Géza & $\begin{array}{l}\text { (Árpád- } \\
\text { Hungary) }\end{array}$ & $\begin{array}{c}\text { Gr.duke of } \\
\text { Hungary }\end{array}$ & $940 / 5$ & $\begin{array}{c}1 \text { February } \\
997\end{array}$ & (1) 967, , (2) 985 & - & ES.II.T.153. \\
\hline István I & $\begin{array}{l}\text { (Árpád- } \\
\text { Hungary) }\end{array}$ & $\begin{array}{l}\text { King of } \\
\text { Hungary }\end{array}$ & $969 / 75$ & $\begin{array}{l}15 \text { August } \\
1038\end{array}$ & 996 & (Stephen) & ES.II.T.153. \\
\hline \multirow[t]{2}{*}{ Gisela } & \multirow[t]{2}{*}{$\begin{array}{l}\text { (Ottonen- } \\
\text { Bayern) }\end{array}$} & \multirow[t]{2}{*}{$\begin{array}{l}\text { Queen of } \\
\text { Hungary }\end{array}$} & $(985)$ & 7 May 1065 & 996 (István I) & 1045:noun & ES.II.T.153. \\
\hline & & & (985) & 7 May 1065 & 996 (István I) & 1045:noun & ES.I/1.T.10 \\
\hline Imre & $\begin{array}{l}\text { (Árpád- } \\
\text { Hungary) }\end{array}$ & $\begin{array}{l}\text { Crown } \\
\text { Prince of } \\
\text { Hun. }\end{array}$ & ca.1007 & $\begin{array}{c}4 \text { November } \\
1031\end{array}$ & 1022 & $\begin{array}{l}\text { (Heinrich), } \\
\text { R.C.Saint }\end{array}$ & ES.II.T.153. \\
\hline Sámuel & $\begin{array}{c}\text { (Aba- } \\
\text { Hungary) }\end{array}$ & $\begin{array}{l}\text { King of } \\
\text { Hungary }\end{array}$ & (?) & $\begin{array}{c}\text { July/August } \\
1044\end{array}$ & (?) & $\begin{array}{l}\text { 1st nephew } \\
\text { of István I }\end{array}$ & ES.II.T.153. \\
\hline Péter & $\begin{array}{l}\text { (Orseolo- } \\
\text { Hungary) }\end{array}$ & $\begin{array}{l}\text { King of } \\
\text { Hungary }\end{array}$ & (?) & $\begin{array}{l}30 \text { August } \\
1059\end{array}$ & $\begin{array}{c}\text { (1) } 1031 / 8,(2) \\
1055\end{array}$ & $\begin{array}{l}\text { 1st nephew } \\
\text { of István I }\end{array}$ & ES.II.T.153. \\
\hline András I & $\begin{array}{l}\text { (Árpád- } \\
\text { Hung.) }\end{array}$ & $\begin{array}{l}\text { King of } \\
\text { Hungray }\end{array}$ & (1014) & fall, 1060 & $\begin{array}{c}(1)(?),(2) \\
1037 / 8\end{array}$ & $\begin{array}{c}\text { 2nd nephew } \\
\text { of István I }\end{array}$ & ES II.T.154. \\
\hline Béla I & $\begin{array}{l}\text { (Árpád- } \\
\text { Hungary) }\end{array}$ & $\begin{array}{l}\text { King of } \\
\text { Hungary }\end{array}$ & (?) & 1063 & $1039 / 42$ & $\begin{array}{c}\text { 2nd nephew } \\
\text { of István I }\end{array}$ & ES.II.T.154. \\
\hline Salamon & $\begin{array}{l}\text { (Árpád- } \\
\text { Hung.) }\end{array}$ & $\begin{array}{l}\text { King of } \\
\text { Hungary }\end{array}$ & 1052 & (war) 1087 & $\begin{array}{l}1063 \text { Salier } \\
\text { Judith }\end{array}$ & $\begin{array}{c}\text { son of } \\
\text { András I }\end{array}$ & ES.II.T.154. \\
\hline Géza I & $\begin{array}{l}\text { (Árpád- } \\
\text { Hungary) }\end{array}$ & $\begin{array}{l}\text { King of } \\
\text { Hungary }\end{array}$ & $1044 / 5$ & 25 April 1077 & $\begin{array}{l}\text { (1) } 1062,(2) \\
1065\end{array}$ & son of Béla I & ES.II.T.154. \\
\hline
\end{tabular}

\section{Notes}

ES I/1.: Schwennicke, D. Europäische Stammtafeln. Neue Folge. Band I/1., V. Klostermann, Frankfurt/Main, 1998.

ES II.: Schwennicke, D. (Hrg.) Europäische Stammtafeln, Neue Folge. Band II., J. A. Stargardt Verl., Marburg, 1984.

ES XXIX.: Schwennicke, D. Europäische Stammtafeln, Neue Folge. Band XXIX. V. Klostermann, Frankfurt/Main, 2013.

\section{Remarks}

(a) $\left(^{*}\right)$ It is not very clear from this table who were supposed to be the parents of Agatha (see also the text).

(b) Queen Margaret and King Malcolm III had eight children-six sons and two daughtersand three of them were Kings of Scots (ES.II.T.89.):

Edward (c.1071-13 November 1093), killed along with his father in the battle of Alnwick;

Edmund (c.1071—post-1097);

Ethelred, abbot of Dunkeld (Perthshire, Scotland);

Edgar (c.1074 - 11 January 1107), King of Scots, reigned 1097-1107;

Alexander I (c.1078 - 23 April 1124), King of Scots, reigned 1107-1124;

Edith (c.1080-1 May 1118), renamed Matilda, Queen of England; 
Mary (1082-1116), Countess of Boulogne;

David I (St.) (c.1084-24 May 1153), King of Scots, reigned 1124-1153.

Margaret was the second wife of Malcolm III, whose son with his first wife (Ingibiorg Finnsdottir, widow of Thorfinn Sigurdsson, Earl of Orkney), Duncan, was briefly King of Scots in 1094.

(c) To avoid confusion, we mention here that there were also two princesses Margaret (Margit) from the Hungarian royal family (Árpád), (ES.II.T.154/155.):

Margit/Margaret (daughter of King Béla III and his second wife, Anna/Agnes de Châtillon-sur-Loing/Antiochia, ${ }^{*} 1175,+$ post 1223), married to (1) Emperor Isaakios II Angelos of Byzantium; (2) Margrave Boniface of Montferrat, King of Thessalonica; and (3) Nicholas de Saint Omer, Sn. of Boetien.

(St.) Margit/Margaret (daughter of King Béla IV. and Maria Laskarina of Nicaia, *1242, +18 January, 1271), Domenican nun.

\section{References}

Baldwin, Stewart. 2010. The Henry Project: The Ancestors of King Henry II of England. Agatha (Uploaded: 20 June 2010, Corrected: 27 June 2010 and 4 July 2010). Available online: fasg.org./projects/henryproject/data/agath000.htm (accessed on 16 December 2021).

Barna, Bálint. 2006. A középkori Szent Imre kép [The Figure of Saint Imre in the Middle Ages, in Hung.]. Studia Caroliensia 2006: 91-110.

Barrow, Geoffrey Wallis Stuart. 1993. Margarete, Königin von Schottland (+1093). In Lexikon des Mittelalters. München: LexMA-Verlag, vol. VI, Column: 237.

Bartók, Zsófia Ágnes, and Balázs Horváth, eds. 2019. Irások a Pray-kódexröl [Studies on the Pray Codex, in Hung.]. Budapest: Argentum Kiadó.

Bollók, János, and Gyula Kristó. 2020. Szent István király Intelmei és Törvényei [Exhortations and Laws of King Saint István/Stephen, in Hung.]. Budapest: Szent István Társulat.

Bouchard, Thomas J., Jr., and John C. Loehin. 2001. Genes, Evolution and Personality. Behavior Genetics 31: 243-73. [CrossRef] [PubMed]

Bradács, Gábor. 2008. Szent Imre herceg a középkori európai történetírásban [Prince Saint Imre/Emerich in the Medieval European Historiography, in Hung.]. Történeti Tanulmányok (Debrecen) 16: 51-72.

Bresslau, Harry. 1884. Jahrbücher des Deutschen Reichs unter Konrad II. Leipzig: Duncker \& Humbolt, vol. 1, p. 102. First published 1879.

Cheynet, Jean-Claude, and Jean-François Vannier. 2003. Les Argyroi [in French.]. Zbornik Radova Vizantološkog Instituta 40: 57-90. [CrossRef]

Chibnall, Majorie, ed. 1980. Historia ecclesiastica. In The Ecclesiastical History of Orderic Vitalis. General Introduction and Books I. and II.. Orderic(us) Vitalis 1124/42. Oxford: Clarendon Press, vol. 1, p. 178.

Concilium. 2002. Concilium Lateranense, II., anno 1139. Lex continentiae, § 7-§ 20. In Concilia Oecumenica et Generalia Ecclesiae Catolicae. Bologna: Dehoniane.

Cornides, Daniel. 1778. Regum Hungariae qui Seculo XI Regnavere Genealogiam Illustrat. Posonii et Cassoviae: Ioannis Michaelis Landerer. Cubbin, Geoffrey P., ed. 1996. The Anglo-Saxon Chronicle. A Collaborative Edition. Cambridge: D. S. Brewer, MS 6. vol. 6, pp. 75, 82.

Czigány, Lóránt, and H. János Korompay, eds. 2000. Sándor Fest, Skóciai Szent Margittól a Walesi bárdokig [Sándor Fest, From Saint Margaret of Scotland to the Welsh Bards, in Hung.] (Anglo-Hungarian Historical and Literary Contacts). Budapest: Universitas Kiadó.

de Vajay, Szabolcs. 1962. Agatha, Mother of Margaret, Queen of Scotland. Ducuesene Review 7: 71-80.

de Vajay, Szabolcs. 1971. Mathilde, reine de France inconnue. Journal des Savants 4: 241-60. [CrossRef]

Dunphy, Graeme, and Christian Bratu, eds. 2016. De genealogia regum anglorum. In Encyclopedia of the Medieval Chronicle. Medieval Manuscripts in Oxford Libraries. MS Laud. Misc. 668.-Freeman, Elisabeth. Ethelred/Ailred of Rievaulx. 1153/54. Available online: https:/ / doi.org/10.1163/2213-2139_emc_SIM_00054 (accessed on 16 December 2021).

Érszegi, Géza, ed. 2001. Szent Imre legendája [The Legend of Saint Imre, in Hung.]. In Árpád-kori legendák és intelmek. Szentek a Magyar középkorból, I. [Legends and Exhortations from the Age of the Árpáds. Saints from the Hungarian Middle Ages, I., in Hung.]. Budapest: Osiris Kiadó, pp. 56-62, 213-20.

Érszegi, Géza. 2008. Szent Imre a korszerú ifjú [Saint Imre the Up-To-Date Youth, in Hung.]. In Szent Imre millennium a Szentimrevárosban [Saint Imre millennium in Saint-Imre-Town.]. Edited by Tamás Csányi, Beatrix Romhányi and Ágota László. Szentimreváros/Budapest: Budai Ciszterci Szent Imre Plébánia, pp. 39-44.

Faris, David, and Douglas Richardson. 1998. The Parents of Agatha, Wife of Edward the Exile. New England Historical and Genealogical Register 152: 224-35.

Felch, W. Ferrand. 1894. The Ancestry of Agatha: The Byzantine Ancestry of Agatha. Notes \& Queries Series 8: 421-23, 461-62.

Fest, Sándor. 1935. Szent Margit skóciai királyné magyar származása [The Hungarian Descendence of Queen Margaret of Scotland, in Hung.]. Budapesti Szemle 238: 276-305. 
Fest, Sándor. 1938. The Sons of Eadmund Ironside: Anglo-Saxon King at the Court of Saint Stephen. Saint Margaret of Scotland. Archivum Europae Centro-Orientalis 4: 115-46.

Fest, Sándor. 2020. The Hungarian Origin of St. Margaret of Scotland. Berkeley: University of California. First published 1940.

Gombos, Ferenc Albin. 1938. Saint Etienne dans l'historiographie du Moyen Age. Budapest: Sárkány Nyomda.

Green, Judith. 2006. Henry I: King of England and Duke of Normandy. Cambridge: Cambridge University Press.

Guido, Michael Anne, and John P. Ravilious. 2012. From Theophanu to St. Margaret of Scotland: A Study of Agatha's Ancestry. Foundations 4: 81-121.

Hardy, Thomas Duffus, and Charles Trice Martin, eds. 1888. Lestoire des Engels solum la translacion Maistre Geoffrei Gaimar, 1st ed. Gaimar/Guimar, Geoffrey. 1136/37. Cambridge: Cambridge University Press, vol. 1, pp. 202-3, rows $4785-4790$.

Herzog, József. 1939. Skóciai Szent Margit származásának kérdése [The Problem of the origins of St. Margaret of Scotland. in Hung.]. Turul 53: 1-42.

Hlawitschka, Edmund. 2006. Die Ahnen der hochmittelalterlichen deutschen Könige, Kaiser und ihre Gemahlinnen. Ein kommentiertes Tafelwerk. Hannover: Hahnsche Buchhandlung, vol. I, pp. 997-1137, Part 2.

Horvát, István. 1828. Británusok Baranya vármegyében, II. András király uralkodása alatt [Britons in Province Baranya under András II, in Hung.]. Hasznos Mulatságok (első félesztendö [first semester.]) 1828: 331-35.

Humphreys, William. 2003. Agatha, Mother of St. Margaret: The Slavic versus Salian Solutions. A Critical Overview. Foundations 1: $31-43$.

Humphreys, William. 2004. Agatha, "The Greek"-Exploring the Slavic Solution. Foundations 1: 275-90.

Huneycutt, Lois L. 2003. Mathilda of Scotland: A Study in Medieval Queenship. Rochester: Boydell Press.

Ingham, Norman W. 1998. Has a Missing Daughter of Iaroslav Mudryl been found? Russian History 23: 231-70. [CrossRef]

James, Andrew. 2021. The Misterious Magyar Origins of Margaret of Wessex, Hungary and Scotland. Available online: angolmagyarmedia.wordpress.com/2021/11/30/the-mysterious-magyar-origins-of-margaret-of-wessex-hungary-andscotland/ (accessed on 30 November 2021).

Jetté, René. 1996. Is the Mistery of the Origin of Agatha, Wife of Edward the Exile, Finally Solved? New England Historical and Genealogical Register 150: 417-32.

John/Florence of Worcester. 1881. Chronicon ex Chronicis. 1117/18. Hannover: Impensis Bibliofilii Hahniani, Tomus 13. pp. 125-30.

Karácsonyi, János. 1928. Hogyan jutott Szent Eduárd angol király unokaöccse a Magyar királyi családdal rokonságba? [How the Nephew of Saint Edward, King of England, Became Related to the Hungarian Royal Dynasty? in Hung]. Turul 42: 39-43.

Katona, Stephanus István. 1779. Historia critica Regum Hungariae. Pest: Iohannes Michaelis Weingand, vol. II, pp. 97-108.

Keene, Catherine. 2011. Saint Margaret, Queen of the Scots: Her Life and Memory. Ph.D. thesis, Central European University, Budapest, Hungary.

Keene, Catherine. 2013. Saint Margaret, Queen of the Scots. A Life in Perspective. London: Palgrave-Macmillan.

Klaniczay, Gábor. 2002. Holy Rulers and Blessed Princesses: Dynastic Cults in Medieval Central Europe. Cambridge: Cambridge University Press, pp. 132-33.

Kniewald, Károly. 1939. A Pray-kódex miserendje [The Order of Masses in the Pray Codex, in Hung.]. Theologia 6: 11-27, 97-111.

Kohlheim, Rosa, and Volker Kohlheim. 2007. Agatha. Duden: Das grosse Vornamenlexikon, 3rd ed. Mannheim: Dudenverlag.

Koller, Joseph. 1782. Historia Episcopatus Quinqueecclesiarum. Posonii: Michaelis Landerer, vol. II, pp. 86-93.

Kraentzler, Ernst-Friedrich. 1978. The Ancestry of Richard Platangenet and Cecily de Neville. Charlotte: Author, p. 58.

Kristó, Gyula. 2000. Imre herceg (és király) nevéről [On the name of Prince (and King) Imre, in Hung.]. Magyar Nyelv 96: 355-57.

Kurcz, Ágnes, ed. 1983. Árpád-kori legendák és intelmek [Legends and Exhortations from the Árpád-Age, in Hung.]. Gáspár J. Csóka, Géza Érszegi, Ágnes Kurcz, and Flóris Szabó, transs. Budapest: Szépirodalmi Könyvkiadó, pp. 64-65.

Lauder-Frost, Gregory M. S. 2002. Agatha-The Ancestry Dispute. The Scottish Genealogist 49: 71-72.

Magyar, Zoltán. 2000. A liliomos herceg. Szent Imre a Magyar kultúrtörténetben [The Prince with Lilies. Saint Imre in the Hungarian Cultural History, in Hung.]. Budapest: Európa Könyvkiadó, pp. 7-34.

Malcomes, Béla Báró. 1938. Szent István unokája-Szent Margit Skócia királynéja származása és magyarországi szülőföldje [Garnd-daughter of Saint István/Stephen-The Ancestry and Land of Birth of Saint Margaret, Queen of Scotland, in Hung.]. Budapest: Stephaneum Nyomda.

Malcomes, Béla Baron. 1937. The Hungarian Birthplace of St. Margaret of Scotland. The Hungarian Quarterly 3: 704-15.

Mladjov, Ian. 2003. Reconsidering Agatha, Wife of Edward the Exile. The Platangenet Connection 11: 1-85.

Mladjov, Ian. 2015. Bulgarians and Magyars as Allies and Rivals across the Early Medieval Frontiers. Paper presented at South-Eastern Europe in the Second Half of the 10th-The Beginning of the 11th Centuries: History and Culture, International Conference, Sofia, Bulgaria, October 6-8; pp. 63-84.

Moriarty, G. Andrews. 1952. Agatha, Wife of the Aetheling Edward. The New England Historical and Genealogical Register 106: 52-60.

Mufanò, Marcus R., and Jonathan Flint. 2011. Dissecting the Genetic Architecture of Human Personality. Trends in Cognitive Sciences 15: 395-400.

Nemeskürty, István. 1993. Mi magyarok [We Hungarians, in Hung.]. Budapest: Akadémiai Kiadó, p. 35.

O'Brien, Bruce R. 1999. God's Peace and King's Peace: The Laws of Edward the Confessor. Philadelphia: University of Pennsylvania Press, p. 664.

Ostrogorsky, Georg. 1968. Storia dell'Impero Bizantino. Milano: Einaudi Editore, pp. 322-24. 
Papp, László. 1967. Rékavár és 1963 évi felderitő ásatása [Rékavár and its Explorative Excavation in Year 1963, in Hung.]. A János Pannonius Múzeum Füzetei, 12. Pécs: Somogy Megyei Nyomdaipari Vállalat.

Parsons, John Carmi. 2002. Edward the Aetheling's Wife, Agatha. The Platangenet Connection 10: 31-54.

Pavsic, Janko. 2001. Agatha: The Onomastic Evidence. The Platangenet Connection 9: 56-100.

Pray, Georgius. 1763. Annales Regum Hungariae [Annals of the Hungarian Kingdom, in Lat.] Pars II. Vindobonae: Typis Georgii Schulzii Typographi Academici, pp. 27-28.

Pretz, Georg Heinrich, ed. 2012. Monumenta Germaniae Historica. Adam of Bremen. ca. 1070. Charleston: Nabu Press, vol. 7.

Raffensperger, Christian. 2012. Reimagining Europe: Kievan Rus' in the Medieval World, 988-1146. Harvard Historical Studies. Cambridge: Harvard University Press.

Raffensperger, Christian. 2016. Ties of Kinship: Genealogy and Dynastic Marriage in Kyivian Rus'. Harvard Series of Ukrainian Studies. Cambridge: Harvard University Press.

Raffensperger, Christian. 2018. Conflict, Bargaining and Kinship Networks in Medieval Eastern Europe. Byzantinum: A European Empire and Its Legacy. London: Lexington Books.

Ravegnani, Giorgio. 2006. Introduzione alla storia bizantina. Bologna: Il Mulino.

Ravegnani, Giorgio. 2008. Imperatori di Bisanzio. Bologna: Il Mulino.

Ravilious, John P. 2009. The Ancestry of Agatha, Mother of St. Margaret of Scotland. The Scottish Genealogist 56: 70-84.

Reusner, Elias/Eliae. 1592. Basilicon Opus Genealogicum Catholicum. Frankfurt: Nicholai Bassaei, Part 5, p. 3.

Rézbányay, József. 1896. Magyarországi Szent Margit, Skótország királynője [Saint Margaret of Hungary, Queen of Scotland, in Hung.]. Katolikus Szemle 10: 68-97.

Ronay, Gabriel. 1989. The Lost King of England: The East European Adventures of Edward the Exile. Woodbridge: Boydell Press, pp. 109-21.

Runciman, Steven. 1929. The Emperor Romanus Lecapenus and His Reign: A Study of Tehth-Century Byzantinum. Cambridge: Cambridge University Press, Reprinted 1963, 1988.

Sauser, Ekkart. 2000. Margareta. Biographisch-Bibliographisches Kirchenlexikon (BBKL). Herzberg: F. W. Bautz, vol. 17, Column: 898-899. Schmale, Franz-Josef. 2002. Lexikon des Mittelalters. Laterankonzil, II. 1139. München: DTV, vol. 5, Column: $1740-1741$.

Schwartz, Elemér. 1930. Heimrich-Imre. Magyar Nyelv 26: 346-49.

Schwennicke, Detlev. 1984. Europäische Stammtafeln. Neue Folge. Marburg: Stargardt Verlag, vol. II.

Schwennicke, Detlev. 1998. Europäische Stammtafeln. Neue Folge. Frankfurt: Vittorio Klostermann, vol. I/1.

Szabó, János B., and Balázs Sudár. 2021. Az Árpád-ház férfineveiről (970-1301) [On Man's Names of the Árpád Dynasty, in Hung.]. Az Árpádok nyomában [On the Trace of the Árpáds, in Hung.]. Budapest: Eötvös Loránd Kutatási Hálózat, Chapter “Imre". pp. 31-33.

Szakonyi, Balázs. 2020. Réka-vár újratöltve-Nádasd várának rekonstrukciós kísérlete [Réka-vár again-Reconstruction Effort for the Fortified Castle of Nádasd, in Hung.]. Várak, Kastélyok, Templomok Évkönyv, 162-65.

Szentpétery, Imre Emericus, and József Balogh, eds. 1938. Scriptores Rerum Hungarorum. Budapest: Typographiae Reg. Universitatis, vol. II, pp. 619-27.

Thomson, Rodney M., and Michael Winterbottom, eds. 2003. Gesta Regum Anglorum [History of the English Kings, in Lat.]. Gulielmus Malmesbury, William of Malmesburiensis 1225. Oxford: Clarendon Press, vol. 2.

Török, József. 1986. Szentté avatás és liturgikus tisztelet [Canonization and Lithurgical Veneration, in Hung.]. In Müvelödéstörténeti tanulmányok a Magyar középkorból [Studies of Cultural History from the Hungarian Middle Ages, in Hung.]. Edited by Erik Fügedi. Budapest: Gondolat Kiadó, pp. 33-47.

Török, József. 1994. Szent Imre a történelmi kutatások világánál. [Saint Imre at the light of historical research, in Hung.]. In Doctor et Apostol. Edited by József Török. Budapest: Márton Áron Kiadó.

Wikipedia Foundation. 2021. Agatha (Wife of Edward the Exile). October 14. Available online: https://en.wikipedia.org/wiki/ Agatha_(wife_of_Edward_the_Exile) (accessed on 2 December 2021).

Wolf, Armin. 2011. Who was Agatha, The Ancetress of Scottish and English Kings? Fundamentals 3: 503-23.

Wunder, Gerd. 1975. Die letzten Prinzen des angelsächsischen Königshauses. Genealogisches Jahrbuch 15: 81-89.

Xantus, János. 1878. Kik voltak az angol (saxon) hercegek Szent István udvarában és mi lett belőlük? [Who were the English (Saxon) Princes at the Court of Saint István/Stephen and what Happened to Them? in Hung.]. Századok 12: 668-69.

Yorke, Barbara. 1999. Edward, King and Martyr. In Studies in the Early History of Shaftesbury Abbey. Edited by Laurence Keen. Dorchester: Dorset County Council, pp. 99-116.

Zapp, Hartmut. 2002. Zölibat. Lexikon des Mittelalters. München: DTV, vol. 9, Column: 663-666.

Zwir, Igor, Javier Arnedo, Coral Del-Val, Laura Pulkki-Råback, Bettina Konte, Sarah S. Yang, Rocio Romero-Zaliz, Mirka Hintsanen, Kevin M. Cloninger, Danilo Garcia, and et al. 2020. Uncovering the Complex Genetics of Human Character. Molecular Psychiatry 25: 2295-312. [CrossRef] [PubMed] 